\title{
Strategies for Accomplishing the Benefits of China-Pakistan Economic Corridor for Pakistan
}

\author{
Saddam Hussain* \\ Department of International economics \& Trade, Business School, \\ Hubei University, Wuhan, 430062, P.R. China \\ Chunjiao $\mathrm{Yu}$ \\ Open Economy Research Centre, Business School, Hubei University, \\ Wuhan, 430062, P.R.China \\ Muhammad Suleman \\ Department of Management Sciences Hazara University Mansehra Pakistan \\ Sadaf Manzoor \\ School of Leadership, Riphah International University Islamabad 44000, Pakistan
}

\begin{abstract}
CPEC represents a new form of China-Pakistan alliance with the aptitude to broaden and further enhance the political and economic ties of both these countries through mutual trade and development. The total projects, (presently) worth US\$ 70billion offer an all times biggest opportunity to Pakistan to tackle the main hitches to its economic development i.e. energy crisis, poor infrastructure, low foreign direct investment (FDI), limited industrial production, limited and old fashioned technology, unemployment and security issues etc. CPEC's estimated socio-economic changes is going to bring harmony, contentment and stability in the country in general and particularly in the undeveloped and retrograded provinces like Baluchistan and somewhat khaiber Pukhtunkhwa (KPK) by providing employment opportunities in different commercial, construction and production activities. Despite the substantial consequences of CPEC, the project is collared by various internal and external confronts and disputes like India's stances on the project, terrorism and instability of Afghanistan and its spillover to Pakistan and feeling unsecure of other countries in the region, Internally political conflicts between the provinces, security challenges and political controversies regarding the route selection etc. which are to be coped with by Pakistan so that to execute of the mega project of CPEC a beneficial endeavor for Pakistan.
\end{abstract}

Keywords: CPEC, OBOR, Silk Rode, Economic Policy, Foreign Policy

DOI: $10.7176 / \mathrm{JESD} / 12-2-07$

Publication date: January $31^{\text {st }} 2021$

\section{Introduction}

The 21 st century has visualized the setting up of regional and globalized economic strategic upbringing all around the world which has ultimately stimulated geo-economic and geostrategic association amongst regionally dispersed nations (Olds, 2002). Almost every country of the world is interested in the expansion of its economy by exploring various means for trade - a highly beneficent and most important factor in economic growth of any economy (Zukin, 2012). That is why every country of the world has focused on their foreign policy to shape it in a fashion to attract investment from other countries and improve their own trade and production. Pakistan and China being good friends since the $1^{\text {st }}$ day of their independence also gave some special attentions to this subject matter and took some practical steps for the economic development and expansion (U. Javaid \& Jahangir, 2015). China being a strong and large economy felt the need of expanding the economy while Pakistan being a developing country could only focused on developing its economy with the mutual cooperation of China. They identified their own interests and concerns while realizing the fact that their interests could not be accomplished by their lonely competences. Keeping it in mind they restructured their strategies and remodeled policies because they have realized that it is impossible for them to defend their interests with their own capacities. As we know that Highlevel negotiations and diplomatic consultations are the only guaranteed solution of every subject matter so same was the case here amongst these two states about industrial ventures, trade and business, infrastructure development and other areas related to economy. As China has a distinct position and is playing a major role not only in Asian region but throughout the world economy and being the fastest growing economy of the world (Tse, 2010), it has a good relation with Pakistan too. So Pakistan is also agreed to go along with China in the world economic race by holding China's hand for support. The bond between Pakistan and China is not only limited to business and trade dealings, they have a very passionate diplomatic understanding and strategic partnership as well (U. Javaid \& Javaid, 2016). Both the countries often exchange high-level meetings and visits and sign investment and development agreements at government level as well as with private sector investors. For example the Free Trade Agreement (FTA) signed in 2006 - divided into two phases - which was brought into being in 2007. The 
Phase I was completed by December 2012 while the negotiations of Phase II was started by July 2013 - targeting the bilateral trade of worth $\$ 20$ billion (Irshad, Xin, Xuan, \& Arshad, 2016); (Sial, 2014). In February 2009 FTA on Trade in Services was signed which applied in October (Nikomborirak \& Jitdumrong, 2013). Likewise, to further enhance and expand these economic relations keeping in mind their own economic and political interests, Pakistan and China, being good neighbors and business partners also showed their interest in up gradation and expansion of the free existing infrastructure of Pakistan along with the seaport of Gawadar through which China can trade with middle east countries and further African countries following the free existing trade route between Pakistan and China i.e. Karakoram highway (F. Hussain \& Hussain, 2017).

\subsection{Karakoram highway}

Karakorum highway connects China (kashgar) with Pakistan at Khunjerab Pass - further to have access to the seaport on the Arabian sea of Pakistan i.e. Gawadar port (Kreutzmann, 2009). This, around 1,300 km (810 mi) long route joining the Gilgit-Baltistan province to the former Silk Road, which leads to Abbottabad (Pakistan) from kashgar (China). From Abbottabad onward, this highway further extends in the southwest, through a motorway N-35, meeting the grand truck road N-5 near HasanAbdal (Pakistan) (S. Ali, Biermanns, Haider, \& Reicherter, 2019).see fig.1 for detail structure and extensions of Karakorum highway.

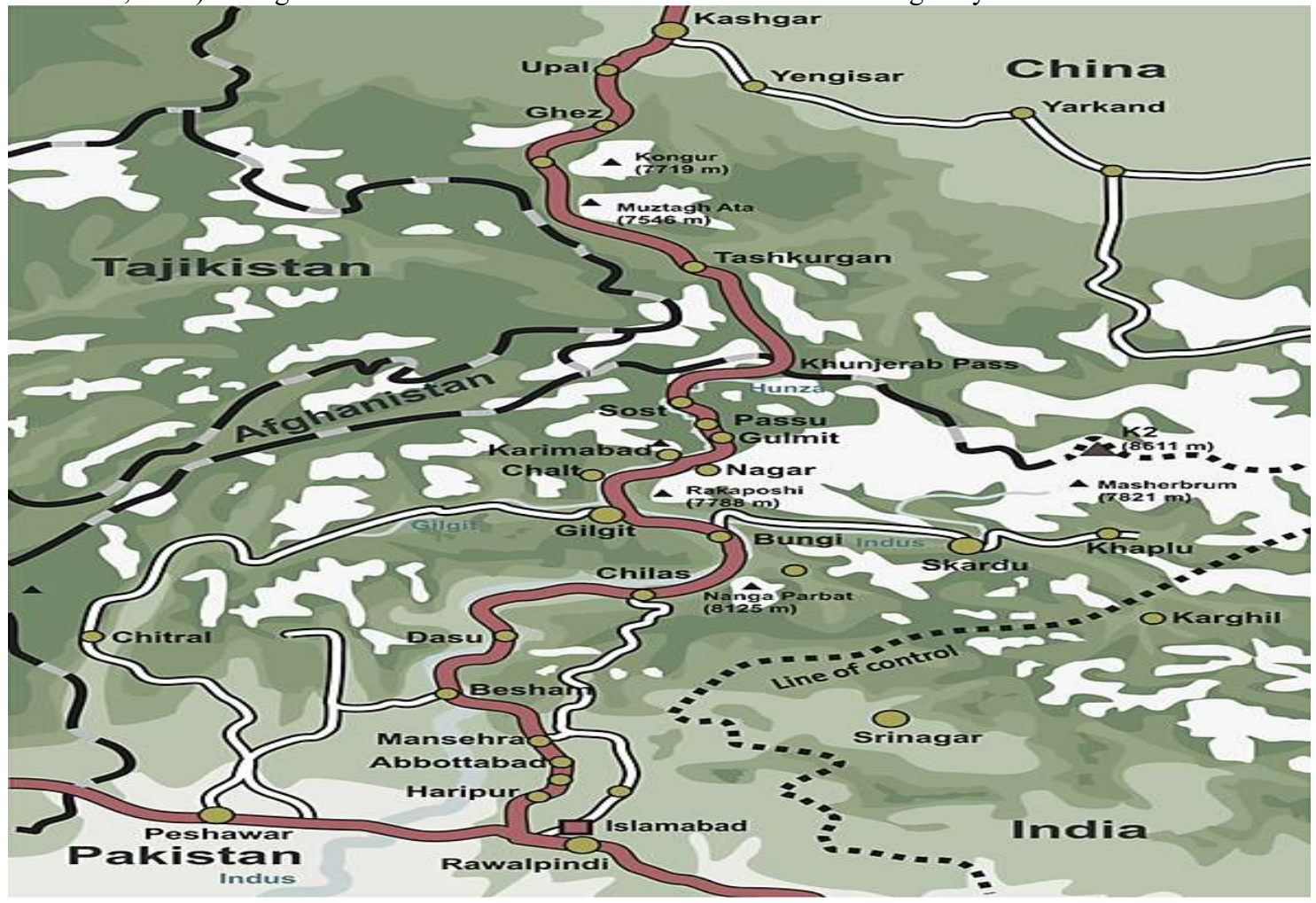

Figure.1. Karakorum highway

Source: https://www.farwestchina.com/travel/karakoram-highway-china-guide/

Pak-China friendship ties keep growing since 1951 and china has always remained a major component of Pakistan's foreign policies and same was the treatment of China with Pakistan. China being a strong candidate of the economic world has always supported Pakistan and their firm friendship is famous all over the world. On the basis of such firm relation and economic and geographic importance for each other, both the countries revived and stimulated the historic Silk Road -the oldest well-known trade route in the world- by their collaborative efforts (Wood, 2002). This route was further extended so that to provide an access to Gawadar port for China (kashghar) which makes Pakistan strategically of enormous significance in the region (Kalim, 2020). The route was named as China Pakistan Economic Corridor (CPEC) (Bhattacharjee, 2015). CPEC is basically an extended branch of China's "One Belt, One Road" scheme that bridging two paramount economic corridors i.e. Silk Road Economic Belt and Southeast Asian Maritime Silk Road (Irshad, 2015).

\subsection{The 21st Century Maritime Silk Road}

The 21st Century Maritime Silk Road generally term as Maritime Silk Road (MSR) is the seaway channel and an extended branch of the Chinese strategic initiative named as Belt and Road Initiative which aims to enhance asset 
speculation and encourage mutual cooperation across the historical Silk Road (Lim, 2015). The Maritime Silk Road initiative was recommended for the first time in October 2013, by Chinese leader Xi Jinping on his visit to Indonesia during his speech to the Indonesian Parliament (https:/www.fmprc.gov.cn/mfa_eng/wjdt_665385/zyjh_665391/t1465819.shtml ). The project is actually building on the maritime expedition channels of Admiral Zheng He. The maritime silk road basically starts from the Chinese coastline to the south through Hanoi to Jakarta, Singapore and Kuala Lumpur through the Channel of Malacca passing through the Colombo (Sri Lankan) in the direction of the southern tip of India passing from Malé, to the Mombasa (East African),further from there onward to Djibouti, then via the Red Sea through the Suez Canal toward the Mediterranean and from there via Haifa, Istanbul and Athens toward the Upper Adriatic region to the northern Italian hub of Trieste along with its international free port and its railways connections in the Central Europe and the North Sea (https://en.wikipedia.org/wiki/21st_Century_Maritime_Silk_Road). Fig.2 shows the detail proposed plan of New Silk Road Initiative.

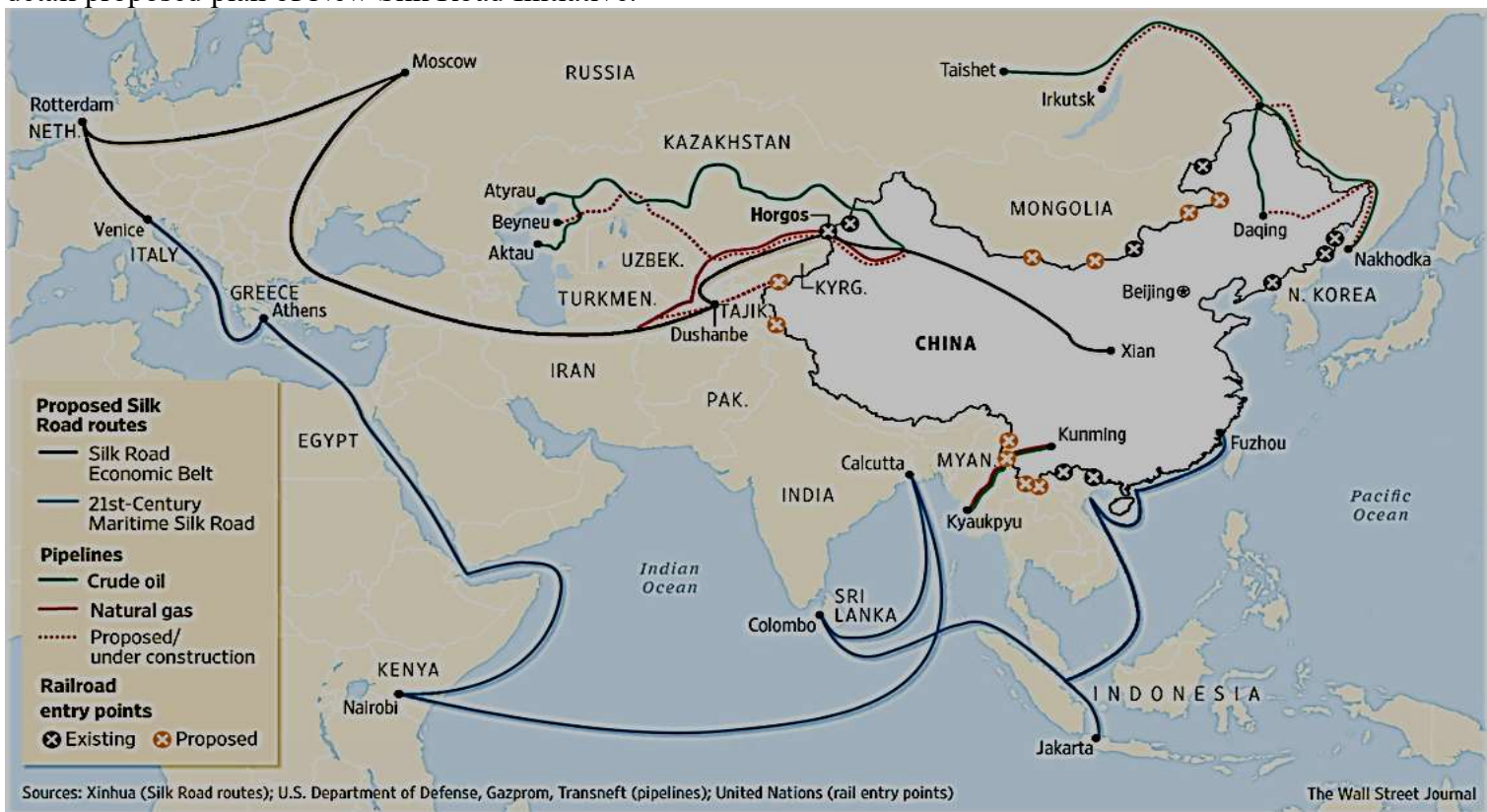

Figure.2 Proposed map of New Silk Roads Initiative

Source: https://territoreality.files.wordpress.com/2014/11/screen-shot-2014-11-10-at-12-50-16-pm1.png

The plan was then announced in November 2014, in order to collect a developmental fund of $\$ 40$ billion for the construction of New Silk Road and Maritime Silk Road (MSR).China has enhanced its effort to attract and involve Africa into the plan of MSR by accelerating the construction of a modern standard-gauge railway network between Nairobi and Mombasa (https://www.wsj.com/articles/china-to-contribute-40-billion-to-silk-road-fund1415454995). The National Development and Reform Commission (NDRC) of China published an article that titled "Vision and Actions on Jointly Building Silk Road Economic Belt and 21st-Century Maritime Silk Road" in March 2015, which explores the doctrines, benefits, Cooperation Priorities, Cooperation Mechanisms, China's Regions in Pursuing Opening-Up, Framework and detailed agenda of the scheme (https://web.archive.org/web/20181127225143/http://en.ndrc.gov.cn/newsrelease/201503/t20150330_669367.ht $\mathrm{ml})$.

\subsection{Overview of One Belt One Road's Initiative}

One Belt One Road (OBOR) is a hobbyhorse of Chinese President Xi Jinping for the economic expansion through mutual association and collaboration amongst the economies across the regions of Africa, Asia, Middle East and Europe to enhance and facilitate trade activities and make approach to every country of the region in an economical and secure way (Clarke, Small, \& Keough, 2017); (Huang, 2016); (Liu \& Dunford, 2016). The idea of "One Built One Road" is of massive strategic significance throughout the region by covering almost 63 percent of the world population which is equal to 4.4 billion, more than 60 countries and the World's economic volume of 29 percent, that worth US\$21 trillion (Liu, Zhang, \& Xiong, 2020); (Johnson, 2016). The One Belt, One Road initiative performs substantial role in the evolution of several cultural, political, strategic domains, educational disciplines, technological fields and economic realms of the region.

The key objective of this corridor is to establish a strong mutual relationship, expand economic activities, encourage trade by shrinking the distances amongst the countries through a common route, enhance transportation 
system, energy and mining projects through public and private investment from the economies of the region and create a politically friendly and flexible environment in the region (Casarini, 2015); (Ohashi, 2018); (Saddam Hussain, Sohail, Yu, Manzoor, \& Zahid, 2020).

The "One Belt One Road"' is a pattern of three different routes i.e. southern, central and northern route. See fig 3.

1. Southern Corridor: This corridor starts from Guangzhou, passing through the western parts of China and then Kashghar; from there the route leads straight to Gawadar port on the Arabian Sea in Pakistan.

2. Central corridor: This is a stand by option with China for approach to international market, if they failed to complete the CPEC in Pakistan to provide the required infrastructure in time. This corridor originates from Shanghai and interconnects China with Tashkent, Tehran and stops at Bandar Imam-e-Khomeini in Iran.

3. Northern corridor: This is a third option for China which originates from Beijing, passes through Russia and finally approaches Europe (Haralambides, 2016).

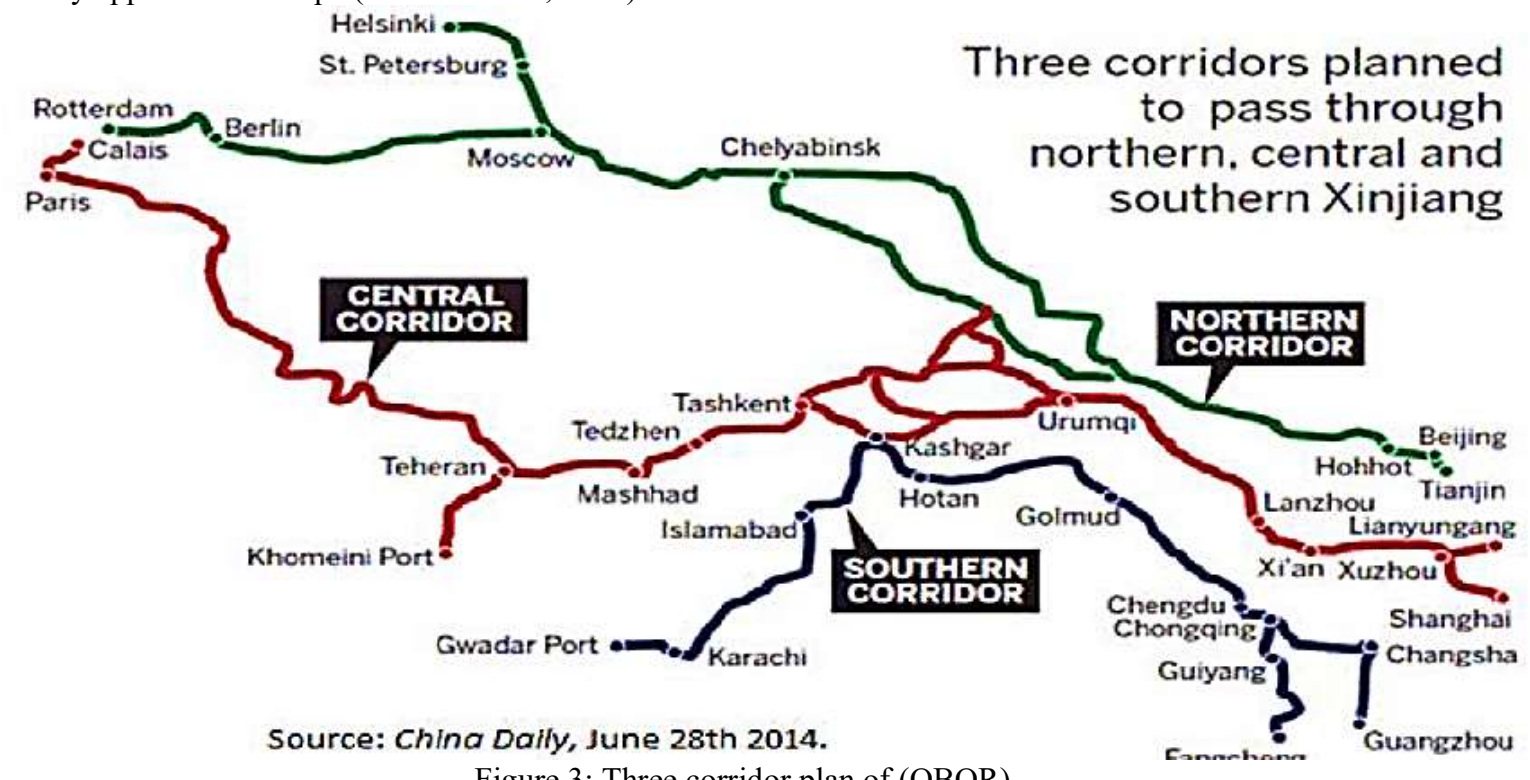

Figure 3: Three corridor plan of (OBOR)

Source: China Daily, June 28TH 2014

So as a whole, this vision will bring political reform and economic prosperity in the region for the present and future generations of the region by inter-connecting Asia, Middle East countries, Africa and Europe by means of a patchwork of free trade zone, modern economic infrastructure and political diplomacy (Swaine, 2015); (Cooley, 2016). As a sponsorship initiative, One Belt, One Road openly exposes Chinese aspirations to encourage trading openings with its neighbor counties i.e. Pakistan, Afghanistan, India etc. traditional partners i.e. Russia, Mongolia, Kazakhstan etc. as well as Central Asia, Europe and Africa. By analyzing in details, we can come across the conclusion that it's not just a plan with multimodal logistics plans, but an impressive political and economic expansion project. It is considered to be the future of trade between East and West and a game-changer project in long-run for the region if the risk of political conflict in the region is neglected or abated (Sharma \& Kundu, 2016).

\subsection{Summary of China Pakistan Economic Corridor}

It's been long, can be traced back to the administration of General Pervez Musharraf in Pakistan, since the scheme is in practice, after an extensive scrutiny and groundwork of feasibility report for the long run economic accomplishments, financial security and solidity of this project mega project for both the countries i.e. Pakistan and China and ultimately, in May 2013, it gained traction after the visit of Chinese Premier Li Keqiang to Pakistan. The landmark of CPEC was signed at that time and after that further eight agreements amounting around $\$ 18$ billion were signed by Nawaz Sharif after his visit to China in the same year. The plan of CPEC was further discussed by the president Mamnoon Hussain on his visit to Beijing in 2014. Initially CPEC valued at US \$47 Billion, the value increased due to the addition of energy projects, railways and communication infrastructures and industrials zones. Presently, the value of CPEC projects has crossed the number $\$ 70$ Billion. ("A flurry of infrastructure cheques from China put Pakistan back in the Belt and Road game". The Times of India. 17 July 2020. Retrieved 23 November 2020). The construction period of CPEC is from 2014 to 2030 (Sajid Hussain \& Khan, 2017). Being a very mega project and large time spam, it is divided into three phases namely, short-term, mid-term and long term projects.

Short-term projects were to be accomplished by 2017; mid-term and long-term are estimated to be completed 
by 2025 and 2030 respectively. The first phase included elaboration and expansion of Gawadar seaport along with an international airport. These were to be completed by 2017. $2^{\text {nd }}$ and $3^{\text {rd }}$ phases included Karakoram Highway expansion, railway networks' up gradation from Karachi to Peshawar, and a Fiber-Optic communication plan. Figure. 4 shows the proposed CPEC plan from Gawadar to Kashgar.

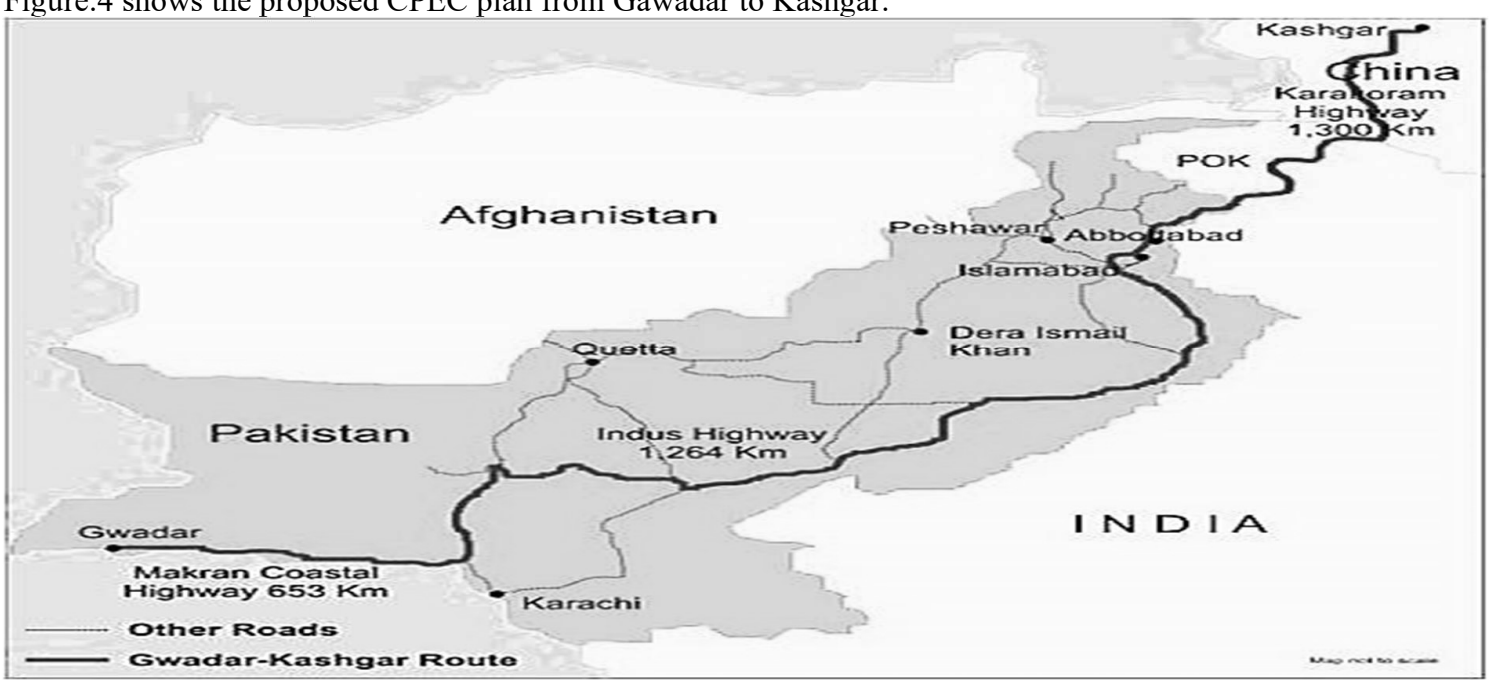

Figure.4 CPEC proposed plan

Source: https://encrypted-

tbn0.gstatic.com/images?q=tbn:ANd9GcQ2leQ40yEHUkWArF1FaH755rMoDJOG3waWWw\&usqp=CAU

It's not a name of a route only; it's a gigantic project, a combination of up grading and expanding energy projects, expanding and up grading the existing infrastructure, industrialization and development of Gawadar Port. See Fig 5.

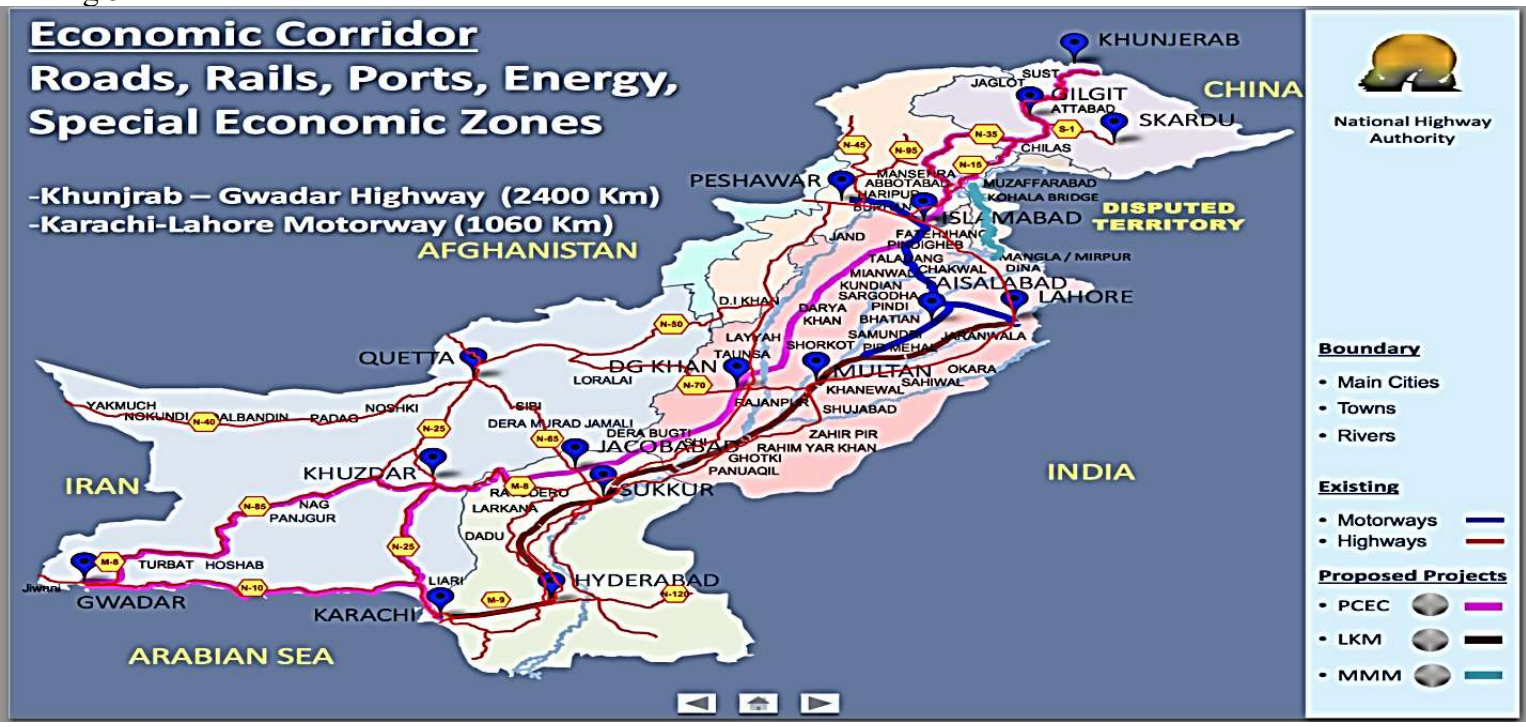

Figure .5 CPEC plan and projects under CPEC plan.

Source: https://qph.fs.quoracdn.net/main-qimg-e3f5430713a6d2a968182dc8a06fa82d.webp

Furthermore, CPEC is deemed as a major component of regional prejudice and economic collaboration in South Asia for China and for Pakistan too, it has great potentials i.e. socially, economically as well as geographically (Saddam Hussain et al., 2020). Table 1 shows the detailed list of the projects under the CPEC mega plan. 
Table 1: Major projects under CPEC plan with detail summary

\begin{tabular}{|c|c|}
\hline Project & status \\
\hline Gwadar Port & Phase 1 complete. Phase 2 under construction. \\
\hline Gwadar-Turbat-Hoshab (M-8) (193 km) & Completed. \\
\hline Surab-Hoshab (N-85) (449 km) & Completed. \\
\hline Dawood wind power project (50 MW) & $\begin{array}{l}\text { Commercial operation date (COD) } 5 \text { April } \\
\text { 2017. Fully operational. }\end{array}$ \\
\hline $\begin{array}{l}\text { Reconstruction of the Karakoram Highway Phase II (Thakot } \\
\text {-Havelian Section) }(118 \mathrm{~km})\end{array}$ & $\begin{array}{l}\text { Project substantially completed by March } \\
2020 \text {. }\end{array}$ \\
\hline Multan-Sukkur Motorway (M-5) (392 km) & $\begin{array}{l}\text { Project Completed and inaugurated on } 5 \\
\text { November } 2019 \text {. }\end{array}$ \\
\hline Abdul Hakeem-Lahore Motorway (M-3) (230 km) & $\begin{array}{l}\text { Project has been completed and inaugurated on } \\
30 \text { March } 2019\end{array}$ \\
\hline Hakla D.I Khan Motorway (285 km) & Completion Planned in December 2020. \\
\hline Karot Hydropower Project (720 MW) & $\begin{array}{l}50 \% \text { civil work completed. Expected COD } \\
\text { December } 2021 .\end{array}$ \\
\hline Kohala Hydropower Project, AJK (1100 MW) & expected completion in 2026 \\
\hline Azad Pattan Hydel Project, AJK (701 MW) & $\begin{array}{l}\text { Expected commercial operation date (COD) } \\
2026 \text {. }\end{array}$ \\
\hline Khuzdar-Basima Road N-30 (110 Km) & Physical work under progress. \\
\hline Orange Line (Lahore Metro) & $\begin{array}{l}\text { Project is completed and inaugurated on Oct } \\
25,2020 \text {. }\end{array}$ \\
\hline Pakistan Port Qasim Power Project (1320 MW) & Project has been completed on 25 April 2018 \\
\hline Quaid-e-Azam Solar Park (1000 MW) & $\begin{array}{l}\text { Under construction First phase complete, } \\
\text { generating } 400 \mathrm{MW} \text { of electricity. }\end{array}$ \\
\hline Sahiwal Coal Power Project (1320 MW) & Completed in July 2017 . In operation. \\
\hline Pakistan-China Fiber Optic Project & $\begin{array}{l}\text { Project has been completed and inaugurated on } \\
13 \text { July } 2018\end{array}$ \\
\hline $\begin{array}{l}\text { Expansion and reconstruction of existing Line Karachi- } \\
\text { Peshawar Line ML-1 }\end{array}$ & $\begin{array}{l}\text { ECNEC approved the project on } 5 \text { August } \\
2020 \text {. }\end{array}$ \\
\hline $\begin{array}{l}\text { Havelian Abbottabad Dry Port (450 M. Twenty-Foot } \\
\text { Equivalent Units) }\end{array}$ & Framework agreement signed in May 2017 \\
\hline Gawadar East Bay Expressway & $\begin{array}{l}\text { Construction work underway. Date of } \\
\text { Completion October, } 2020 \text {. }\end{array}$ \\
\hline Pak China Friendship Hospital & Groundbreaking held on 16 December 2019. \\
\hline New Gawadar International Airport & Construction work started on 31 October 2019. \\
\hline Gwadar-Nawabshah LNG terminal and pipeline project & Approved \\
\hline UEP 99 MW Wind Farm (Jhimpir, Thatta) & $\begin{array}{l}\text { Commercial operation date (COD) } 16 \text { June } \\
\text { 2017, Operational }\end{array}$ \\
\hline Sachal 50 MW Wind Farm (Jhimpir, Thatta) & $\begin{array}{l}\text { Commercial operation date (COD) attained } 11 \\
\text { April 2017, Operational }\end{array}$ \\
\hline $\begin{array}{l}\text { Three Gorges Second and Third Wind Power Projects (100 } \\
\text { MW) }\end{array}$ & $\begin{array}{l}\text { Commercial operation date (COD) attained } 9 \\
\text { Jul 2018, Operational }\end{array}$ \\
\hline Cacho 50 MW Wind Power Project & LOI ( letter of intent) Stage \\
\hline Western Energy (Pvt.) Ltd. 50 MW Wind Power Project & Approved \\
\hline $\begin{array}{l}\text { Thar Mine Mouth Oracle Power Plant (1320 MW) \& Surface } \\
\text { Mine }\end{array}$ & Under issuance of NTP/LOI \\
\hline HUBCO Coal Power Project, Hub Baluchistan (1320 MW) & COD is 14 Aug 2019, fully operational. \\
\hline Phandar Hydropower Station (80 MW) & under review of experts from both sides \\
\hline Gilgit KIU Hydropower (100 MW) & under review of experts from both sides \\
\hline Matiari to Lahore Transmission Line $(878 \mathrm{Km})$ & Expected COD in March 2021. \\
\hline Suki Kinari Hydropower Project (870 MW) & $\begin{array}{l}\text { Under construction, Commercial operation date } \\
\text { (COD) December } 2022 .\end{array}$ \\
\hline $\begin{array}{l}\text { SSRL Thar Coal Block-I } 6.8 \text { Mtpa \&SEC Mine Mouth Power } \\
\text { Plant }(2 \times 660 \mathrm{MW})\end{array}$ & $\begin{array}{l}\text { First Unit ( } 660 \mathrm{MW}) \text { is targeted by Aug } \\
\text { 2022.COD of complete project is targeted by } \\
\text { Feb } 2023 \text {. }\end{array}$ \\
\hline $\begin{array}{l}\text { Surface mine in block II of Thar Coal field, } 3.8 \text { million } \\
\text { tons/year }\end{array}$ & Thar block II unearths coal on 10 June 2018 \\
\hline Engro Thar Block II $2 \times 330 \mathrm{MW}$ Coal fired Power Plant & COD is 10 July 2019 . In operation. \\
\hline
\end{tabular}


HUBCO Thar Coal Power Project (Thar Energy) (330 MW) Expected completion in March 2021

Thal Nova 330 MW Mine Mouth Lignite Fired Power Project Expected completion in March 2021

at Thar Block-II, Sindh, Pakistan

Imported Coal Based Power Project at Gawadar, Pakistan Groundbreaking done on 4 November 2019.

(300 MW)

Khunjerab Railway

Feasibility studies underway

China Pakistan Economic Corridor Businessman Networking Under Growing - Membership Open for

business community

Source: https://en.wikipedia.org/wiki/China\%E2\%80\%93Pakistan_Economic_Corridor

Although CPEC seems to bring a reform in the out-look of Pakistan's economy by improving infrastructure, meeting her energy shortages, developing industrial and free trade zones (Haq \& Farooq, 2016). Cost/benefit analysis of CPEC suggests that it can potentially boost up Pakistan's economy by making it as a region trade hub in Asia (Khan, 2017). Simply we can say that CPEC is a fat-changer project for Pakistan but still there are some serious challenges which Pakistan has to cope with and cash in on CPEC in an efficient way. This paper aims to highlight the hindrances and the possible constructive measures to be taken for the solution.

\section{Challenges in the smooth run of CPEC for Pakistan}

CPEC is being modeled in a manner that it will not just stimuli Pakistan's economic growth but it will also offer base for socio economic elaboration, regional integration, interoperability, consistent development and efficient disciplining of its properties - all of which are aligned with the Sustainable Development Goals (SDGs). It is not just an economic venture; it has various strategic, cultural, civilizational and political scopes and aspects. Basically the project is considered simply as a geo-economic, but after its implementation and execution it will prove itself to be transformative for bordering territories of East Asian countries, Central Asian countries, South Asian countries, West Asian countries, the Gulf and African countries. It is expected that CPEC will act as a vehicle for linking regional economies by providing them a channel which will make Pakistan a hub for domestic and global trade (http://cpec.gov.pk/messages/10).

Bearing the output of Cost/benefits analysis of CPEC in mind (L. Ali et al., 2018); it is simply a win-win scenario for both Pakistan and China. But to guarantee the surety of, whether it will happen as it is stated and expected, totally rest on effective and timely accomplishment of the project, assurance of unambiguity, work efficiency and transparency. There are two types of challenges for Pakistan to cope with;

\subsection{Internal challenges}

Internal challenges are as; political instability, security risks, illiteracy, lake of technical education, security, insufficient technology etc. (Abid \& Ashfaq, 2015);(A. Ali, 2015);(Sultan, Omar, \& Imtiaz, 2019);(U. Javaid, 2016)

\subsection{External challenges}

External challenges are; rival neighboring countries like India, sometimes Iran also feel insecure from the Gawadar seaport, Afghanistan as well, pushed by Indian disparagers (Ashraf, Shafiq, \& Batool, 2017);(M. Hussain, 2017).

\section{Steps to be taken by Pakistan to cash in on CPEC}

CPEC is the project which can change the fate of Pakistan and can uplift and spark the economic outlook of the country (Abid \& Ashfaq, 2015); (Malik, 2018). Too many opportunities are knocking at the door but to invite them inside, Pakistan should cope with the problems that are making hazards in its way coming in the country and impeding the mega project of CPEC (A. Ali, 2015); (U. Javaid, 2016). China is investing the highest amount a country has ever invested in Pakistan. This heavy investment is not less than a blessing for Pakistan. As we can see in table 1 CPEC comprises variety of projects which will enable Pakistan to cope with its entire internal problems i.e. underprivileged infrastructure, energy Shortage, below standard industrial infrastructure, low balance of trade deficits etc. Energy and infrastructure projects under CPEC will reshape Pakistan's economy by creating opportunities of investment for the foreign and local investors in the country. Apart from collaboration in industrial, agriculture, energy and finance sectors, tourism industry Pakistan will also be promoted which will ultimately produce some virtuous opportunities of investments by attracting foreign direct investment (FDI) - a key factor in economic development (Lenka \& Sharma, 2014).

Apart from all the above facts that CPEC is about bringing diversity in social and economic conditions of Pakistan but still it cannot be an overall win-win project, until Pakistan cope with the challenges it faces like, insurgence in Baluchistan, political conflict among provinces, political flux, technicality and external strains on Pakistan (Iqbal, 2018); (M. Hussain, 2017); (Arif, 2018).

Pakistan has to take the following steps -that can be considered as the secret of economic development of any economy - to cash the benefits of CPEC in a beneficial way; 
$>$ Education (Ozturk, 2008).

$>$ Security (Internal And External) (Tschirgi, Lund, \& Mancini, 2010).

$>$ Political Stability (P. D. U. Javaid \& Haq, 2020).

$>$ Economic Policies (Krueger, 1997);(Keesing, 1967).

> Foreign Policies (Lu \& Ram, 2001); (Lall \& Narula, 2004).

$>$ Political dynamics (Lindberg, 1963); (Saeed, 1986).

$>$ Political And Diplomatic Relations (Lee \& Hudson, 2004);(Baranay, 2009).

$>$ Trade And Economic Relations (Haberler, 1961); (Brauer \& Dunne, 2004).

\subsection{Education}

Education is one of the elementary factors of development in almost every sense for an economy (Gylfason, 2001). It enhances people's tolerance, considerations, intellects, perception and intelligence, ability of work, sense, awareness, knowledge, concept and acceptance power for their selves and for rest of the world (Bentley, 2012); (Brown \& Lauder, 1996). It upgrades the standard of their livings and leads to innovative and broad minded society which benefits the individuals and society as a whole by enhancing people's efficiency, inventiveness, stimulates entrepreneurship and technological improvements that play a vital role in securing a social and economic progression (Goldin \& Katz, 2009). Exclusive of significant investment in human capital - to educate them - no any nation can possibly accomplish viable economic elaboration (Ozturk, 2008). Hence, it is quite obvious that no rise and success is possible without developing a strong educational infrastructure. So to cash the benefits of CPEC Pakistan should take steps to educate its people and improve the quality of education to avail the opportunities of new technological change, business and trade expansions and investment opportunities. Although an economy cannot be transmuted by education alone but it can play a vital role in the solution of almost overall problems Pakistan is facing - political unawareness, business and trade unawareness, internal conflicts between political parties and provinces, insurgence, terrorism and corruption etc. (Coleman, 2015);(Bush, 2008). There has been a positive relation of better quality education to better income equality, which, in words, quality education favors higher economic growth rate. Education and awareness benefit the people with low-income comparatively more by seeking more economic opportunities. (Psacharopoulos \& Ng, 1992). Same is the case in Pakistan, majority of people are middle class or low-income, so the education will help them more to seek for the economic opportunities i.e. employment and investments etc. offered by CPEC. That is why Pakistan has to pay a serious attention to invest on their countrymen in the form of improving their quality of education. Pakistan should focus on the following educational fields in particular;

- Business and commerce education

- Technical education

- Scientific and computer related education.

As CPEC includes industrial zones and trade improvement project which ultimately need skilled and business minded people to promote it and get the benefits. Similarly technical labor will have a great demand in the country after establishing all the energy and production projects so Pakistan has to focus to educate people on technical side as well, in order to cash the services gains and employment opportunities at home. Scientific research and computer literacy programs should be given a proper attention as it is considered the key element of technological development in the present era. So, if Pakistan wants to hold CPEC's enormous benefits, then these factors should be given the priority.

\subsection{Economic policies}

Weight and worth of investment, both from national and international investors in a country greatly depends upon the economic policies modeled and implemented by the home country (Chang, Kaltani, \& Loayza, 2009); (Kneller, Bleaney, \& Gemmell, 1999); (Turnovsky, 1999); (Nijkamp \& Poot, 2004). As a vivacious element of human selfesteem, sovereignty, personal liberation, economic openness, economy policy is as worthy as objective per se (Hutchison, 2013). Hence it is the fact that economic openness and freedom offers a well-defined formula for economic development and success. An economic policy is a planned series of actions that is proposed to manipulate or influence the behavior of the economy (Delli Gatti, Gallegati, \& Minsky, 1994); (Buchanan, 1987). Examples of economic policies are to comprise the decisions made about government expenditure and taxation, supply of money, income distribution and reallocation amongst rich and poor. While making an economic policy, the policy makers take under considerations three major types; Fiscal policy, Monetary policy, Supply-side policy. So, Pakistan has to focus on its present and future craves to formulate the policies in such a fashion to help Pakistan flourish its economy by cashing in on CPEC in an efficient way. For example;

- Fiscal policy: The government should rise its spending in more productive and beneficial projects in parallel to the projects of CPEC in order to strengthen the projects and cash the public confidence in spending in CPEC projects. Reduce the taxes charges and so that to increase the investment from local as well as foreign investors. This will ultimately boost Pakistan's foreign direct investment which is a good 
sign for economic growth.

- Monetary policy: As per monetary policy Pakistan has to increase the money supply in the market so the interest rate will be decreased and loans will be provided on easy conditions to the investors. This will help the investors to invest more in the production and energy projects of CPEC and will ultimately result in increase in the overall GDP of the country by increasing net exports. Exports will increase because a decrease in the interest rate causes home currency less charming and attractive as compared to the foreign currency ultimately causes exports cheaper while making imports more costly. In such a way the free industrial zones under the CPEC project will play its role in the overall production growth which will further generate employment opportunities for the locals of Pakistan.

- Supply-side policy: As CPEC is improving infrastructure and increasing the energy generation which will ultimately invite the foreign industrialist to open their branches in Pakistan. Apart from that CPEC projects also include industrial development and expansion. The government has to help them boost the production volume, facilitate them through giving subsidies and facilitate them for the export of the surplus goods. So that the production increases which will help Pakistan's' economy to bloom. Additionally the government should give incentives and encourage the research and development sectors in order to promote innovation and technological development to cash the benefits of foreign investors in Pakistan being technical and efficient producers and innovators.

Furthermore, the government should promote free trade support skilled migrations, offer tax incentives and direct grants for research and development (R\&D), train and educate people who study in science, technology, engineering, and math (STEM) field, offer Incentives for Research based organizations and University researchers and invest on Mission-Oriented Projects (MOP).

\subsection{Foreign policies}

As major aims of Pakistan's foreign policy are how to stimulate the internationally renowned norms of interstate administrative relations i.e. honor and value for sovereignty and regional integrity and veracity of all other states, no interruption in the state affairs of other states; no violence or any offensive actions against other states and settle down all the disputes in a peaceful discipline. Basically a foreign policy seeks the goals and targets abroad, attainment of the values that arise to those goals and objectives and the measures or mediums utilized to pursue them. As at present time Pakistan has tied all its hopes with the projects of CPEC, a multi dimensions project including energy sector, industrial expansion and production sectors, infrastructure developing projects etc. As energy growth and infrastructure development plays a key role in economic affluence and the bilateral trade of a state and CPEC is developing both these factors in a promising way. This will give a boost to Pakistan's economy if Pakistan shapes its foreign policies in fashion which give rise to a healthy relationship of Pakistan with its neighbors and faraway countries. Hence, CPEC is providing a platform to the foreign investors by enhancing energy generation capacity and developing infrastructure - which are the key factors of enhancing FDI (Wekesa, Wawire, \& Kosimbei, 2016); (Bayliss, Hall, \& Corral, 2001) - and further we know that Foreign Direct Investment (FDI) is greatly influenced by the policies (good or adverse) of the government of a country (Bissoon, 2012); (Globerman \& Shapiro, 1999). So Pakistan has to reshape its foreign policy so that to create a healthy environment both with neighbors and far away countries and make investors-friendly policies so that to make Pakistan a point of attraction for foreign investors. The government has to offer incentives, in the shape of tax reduction and tariff reduction to foreign investors. Because all these measures play a vital role in taking decision to invest in a crossborder destination.

\subsection{Security issues}

As CPEC is a very huge investment plane of china in Pakistan and it is expected that it will bring a reform in the economy of Pakistan which is not unbearable for the rival countries and antagonist organizations in Pakistan (Rafi, 2017). Insurgence and terrorism in Baluchistan and other terrorist attacks on CPEC workers etc. are the some of the examples of their response. First of all India is sponsoring insurgent activities in Baluchistan against Pakistan, which was proved when an Indian spy Kulbhushan Jadhav was arrested in Baluchistan. Secondly, the continuous attacks of the Baloch Liberation Army on CPEC projects and targeting people associated to CPEC i.e. attack on Chinese consulate (Ahmed, 2018). There are two types of security problems;

\section{- Internal security}

Domestic constraints, as discussed above the Baluchistan's situation, similarly the terrorism threat in KPK and Sindh, particularly the city of Karachi. Various anti-state extremists groups like Baluchistan Liberation Army (BLA), Tehreek-e-Taliban Pakistan (TTP), Baluchistan Liberation Front (BLF), Lashkar-e-Jhangvi (LeJ), and the militant groups supported by some political parties for their own interests against the state. These are the internal security issues which has to be solved through stick and carrot strategy so that local investors as well as international investors feel secure and invest in Pakistan and especially in the CPEC projects so that make CPEC more and more expanded and beneficial for Pakistan. 


\section{- External security}

Regional dynamics for example the external security issues of the country where we can count on the first position, is the India followed by Afghanistan's terrorist organizations and somehow a little bit threat can be from the Iran being a competitor country in the form of port Chabahar (Iran) with Gawadar port (Pakistan). So sometimes Iran also feels insecure and can take or support opposing steps of CPEC. Stabilization of affairs with India is quite essential for the CPEC project to be fully succeeded. For that both the countries require changing their mindset during decision making for mutually acceptable relationships, forget about the past happenings and get a new start of friendly relationship. This can be accomplished by chipping away their antagonism and collaborating on policies of common interest, such as to accomplish a secure and established environment in the region for a sustained economic cooperation. Because, for Pakistan, to secure a booming economy and a prosperous state, through the mega project of CPEC, has to reduce strains with all its neighbor countries, particularly with India.

Lastly, USA being an opponent and parallel competitor of China, in alliance with India also tries to interrupt this mega plan of CPEC in Pakistan by pressurizing through Financial Action Task Force (FATF) and International Monetary Fund (IMF).

Therefore, the government of Pakistan has to negotiate with these countries directly or through United Nation Organization (UNO) so that to let the CPEC to be proceeded in a safe and smooth way and also after completion the environment is favorable for traders and investors. This way Pakistan can get maximum output from the CPEC projects and can enjoy the return in the form of economic growth.

\subsection{Regional dynamics}

Political hitches within Pakistan can also disrupt the accomplishment of the CPEC project. Though, major political parties of Pakistan have a consensus on the gains and successfully accomplishing of CPEC but still there are some controversies, mainly on, routes selected priority and work for the development of these routes and the funds allocations to the CPEC projects, amongst various political parties. For example, accuse of Khyber Pakhtunkhwa and Baluchistan for changing the original route on the ploy of security threats by the federal government, which is only benefiting more developed province, Punjab (Iqbal, 2017). History reveals that absence of visions and political conflicts have always stemmed in the establishing of major development projects, political interests always take primacy over national gains and disputes like allotment of resources have always been politicized in the country. Mull over the inherent history of the political economy of Pakistan it is quite obvious that such lacks of political harmony always have a negative effects on the realization of CPEC.

That is why Pakistan has to take additional measures to cherish cohesiveness so that the project does not rest in regional disgruntlements, in order to guarantee cross section of the country benefits from the projects of CPEC. The federal government has to conduct All Party Conferences as once on May 28, 2015 they did to discuss issues related to the CPEC route, so that make the completion of all projects guaranteed and beneficent for all the provinces equally in order to avoid political conflicts amongst the provinces. As, there is a general perception about CPEC-related projects that these are wholly solely controlled by the prime minister and his dearest cabinet members so the decisions are assumed to be made secretively. So the government has to make all the decision in the presence of all provincial cabinet members so that ambiguity and misconceptions do not find any space and all the parties collectively accept and support the mega project. Because, it is quite essential, to confront these issues more seriously, for Pakistan to accomplish local ownership of CPEC projects.

\subsection{Political and Diplomatic Relations}

Rapid transformations are coming about within regional confederacies, which, in order, have reformed local dynamics throughout the world (Taylor, 2008). Pakistan and China have to realize the emerging geopolitical circumstances and modify their strategies correspondingly to respond realistically to the application of the CPEC project. Through communal collaboration and mutual trust, Pakistan and China will triumph in the face of all the potential obstacles twisted by the regional environmental changes. However, in the long run, accomplishment of CPEC will not be restricted to the bilateral economic activities of Pakistan and China only but it will get a support for the diplomatic policies of both these countries from other countries of the region. Hence, through constructive and affirmative diplomatic policy implications, Pakistan can attend the concerns of participating regional countries and can discourage the efforts of the countries trying to emasculate and challenge CPEC. Pakistan has to put across to its neighbors the surety through firm commitment about the implementations of the project. Diplomatic struggles via the course of negotiations and dialogues should target to emphasize the economic grants of CPEC for the entire region. All these determined and emphatic endeavors by Pakistan for the optimistically and constructively engagement of all the investors i.e. traders, industrialists and businessmen, will help Pakistan in execution of the CPEC project in a very secure and beneficent way. 


\subsection{Trade and Economic Relations}

Trade is the epicenter of global poverty and a key element in any economic development. Economies that have an easy and open access to international trade progress faster, modern and enhance productivity, offer more earnings, offer affordable commodities and services and employment opportunities for their locals. For Pakistan being a developing country and a new entry in the trade market through CPEC can cash all these profits only if they let the CPEC complete in the proposed pattern and time period. For that Pakistan has to accomplish a very good trade and economic relations with all the regional and faraway countries to promote trade activities and enhance its economy. Although this trade and economic relations will offer golden opportunities for Pakistan but there are some challenges too which Pakistan has to cope with.

- Incompetent or defective transport system

- Poor telecommunication or information technology system

- Poor financial market

- Complicated regulatory and authoritative environments that discourage new investments

In order to establish an investors-friendly environment in the country to utilize all the opportunities that CPEC is going to offer after completion. For example;

- Enhance trade, attractiveness, competitiveness and expansion

- Supporting and facilitations of trade and transportation logistics

- Provisions for access to local and international markets and trade corporations

- Coping with and managing market shocks and encouraging further inclusion in trade and investment by offering subsidies, tax relief etc.

This way Pakistan can encourage national and international investors to invest in Pakistan and make the CPEC project a more attractive investment opportunity for national and international investor, which will finally strengthen the CPEC with heavy investment and ample of opportunities for the locals of Pakistan, as are expected from this mega project.

\section{Conclusion}

Pak-China relations are as old as these countries are, and their relations evolved gradually in every field including trade and investments (G. Ali, 2017). However the expanding globalization propelled both the countries to expand their economic ties so that to support each other and move forward in the economic competitive world (Zaki, 2014). For this purpose CPEC project is expected to help flourish and recognize both the economies in the world. China being already an expanded and developed economy wants more to boost up and searching for feasible ways and attractive markets while Pakistan being a slow developing economy would like to go abreast China in this race and get the support required to grow its economy by expanding their trade. For this purpose Pakistan has been agreed with China for the mega project of CPEC, which is expected to bring some enormous positive changes in economic growth of Pakistan. It is possible only if all the CPEC projects are completed in due time and deliver its output in way as expected, and it is possible only if Pakistan take the above discussed steps. If Pakistan succeeded in the accomplishment of this milestone, it will be a win-win scenario for Pakistan and it will bring a reform in the economic growth of Pakistan in present as well as for future. In conclusion, socio-economic problems i.e. energy crises, trade deficit, poor infrastructure and unemployment etc. will be greatly solved by the FDI inflows and CPEC (Abid \& Ashfaq, 2015); (Asif, Rehman, Zheng, \& Shah, 2019); (Mumtaz, Smith, \& Khan, 2017). Therefore, the government of Pakistan has to give decorous considerations to policies interpretation regarding CPEC.

\section{References}

Abid, M., \& Ashfaq, A. (2015). CPEC: Challenges and opportunities for Pakistan. Journal of Pakistan Vision, $16(2), 142-169$.

Ahmed, M. (2018). The economics and politics of China Pakistan Economic Corridor and Balochistan. Regional Studies, 36(4), 71-111.

Ali, A. (2015). China Pakistan Economic Corridor (CPEC): Prospects and challenges for regional integeration. International Journal of Social Sciences and Humanity Studies, 7(1), 1-15.

Ali, G. (2017). China-Pakistan relations: A historical analysis: Oxford University Press Karachi.

Ali, L., Mi, J., Shah, M., Shah, S. J., Khan, S., Ullah, R., \& Bibi, K. (2018). Local residents' attitude towards road and transport infrastructure (a case of China Pakistan economic corridor). Journal of Chinese Economic and Foreign Trade Studies.

Ali, S., Biermanns, P., Haider, R., \& Reicherter, K. (2019). Landslide susceptibility mapping by using a geographic information system (GIS) along the China-Pakistan Economic Corridor (Karakoram Highway), Pakistan. Natural Hazards \& Earth System Sciences, 19(5).

Arif, A. (2018). CPEC: a continuum of opportunities and challenges for Pakistan. South Asia@ LSE.

Ashraf, M., Shafiq, A., \& Batool, S. (2017). China Pakistan Economic Corridor (CPEC): analysis of internal and 
external challenges. International Journal of Business, Economics and Management, 4(5), 106-111.

Asif, M., Rehman, F. U., Zheng, L., \& Shah, H. (2019). Does trade with China can make growth in Pakistan more inclusive? pre and post empirical impact of China-Pakistan economic corridor. Developing Country Studies, 9(3), 57-67.

Baranay, P. (2009). Modern economic diplomacy. Publications of Diplomatic economic club, $20,8$.

Bayliss, K., Hall, D., \& Corral, V. P. (2001). FDI linkages and infrastructure: some problem cases in water and energy. Public Services International Research Unit (PSIRU).

Bentley, T. (2012). Learning beyond the classroom: Education for a changing world: Routledge.

Bhattacharjee, D. (2015). China Pakistan economic corridor. Available at SSRN 2608927.

Bissoon, O. (2012). Can better institutions attract more foreign direct investment (FDI)? Evidence from developing countries.

Brauer, J., \& Dunne, P. (2004). Arms trade and economic development: theory, policy and cases in arms trade offsets (Vol. 8): Routledge.

Brown, P., \& Lauder, H. (1996). Education, globalization and economic development. Journal of education Policy, 11(1), 1-25.

Buchanan, J. M. (1987). The constitution of economic policy. The American economic review, 77(3), 243-250.

Bush, T. (2008). Leadership and management development in education: Sage.

Casarini, N. (2015). Is Europe to Benefit from China's Belt and Road Initiative? : Istituto Affari Internazionali (IAI).

Chang, R., Kaltani, L., \& Loayza, N. V. (2009). Openness can be good for growth: The role of policy complementarities. Journal of development economics, 90(1), 33-49.

Clarke, M., Small, A., \& Keough, J. (2017). China's Belt and Road Initiative: Views from along the Silk Road. Asia policy(24), 65-122.

Coleman, J. S. (2015). Education and Political Development.(SPD-4) (Vol. 4): Princeton University Press.

Cooley, A. (2016). The Emerging Political Economy of OBOR. Recuperado el, 7.

Delli Gatti, D., Gallegati, M., \& Minsky, H. P. (1994). Financial institutions, economic policy, and the dynamic behavior of the economy. Economic Policy, and the Dynamic Behavior of the Economy (October 1994). Jerome Levy Economics Institute Working Paper(126).

Globerman, S., \& Shapiro, D. M. (1999). The impact of government policies on foreign direct investment: The Canadian experience. Journal of International Business Studies, 30(3), 513-532.

Goldin, C. D., \& Katz, L. F. (2009). The race between education and technology: harvard university press.

Gylfason, T. (2001). Natural resources, education, and economic development. European economic review, 45(46), 847-859.

Haberler, G. (1961). Terms of trade and economic development Economic Development for Latin America (pp. 275-307): Springer.

Haq, R., \& Farooq, N. (2016). Impact of CPEC on social welfare in Pakistan: A district level analysis. The Pakistan Development Review, 597-618.

Haralambides, H. (2016). OBOR networks \& maritime geopolitics: The century of Eurasia.

Huang, Y. (2016). Understanding China's Belt \& Road initiative: motivation, framework and assessment. China Economic Review, 40, 314-321.

Hussain, F., \& Hussain, M. (2017). China-Pak economic corridor (CPEC) and its geopolitical paradigms. International Journal of Social Sciences, Humanities and Education, 1(2), 79-95.

Hussain, M. (2017). China Pakistan Economic Corridor (CPEC): Challenges and the way forward: Naval Postgraduate School Monterey United States.

Hussain, S., \& Khan, M. A. (2017). CPEC; A Roadmap of Region's Development. FWU Journal of Social Sciences, 11(2).

Hussain, S., Sohail, A., Yu, C., Manzoor, S., \& Zahid, A. (2020). CHINA-PAKISTAN ECONOMIC CORRIDOR (CPEC'S) SOCIO-ECONOMIC IMPACTS ON PAKISTAN. International Journal of Management \& Entrepreneurship Research, 2(6), 416-436.

Hutchison, T. W. (2013). Positive economics and policy objectives: Routledge.

Iqbal, K. (2017). Significance and security of CPEC: A Pakistani perspective. China Int'l Stud., 66, 132.

Iqbal, K. (2018). Securing CPEC: Challenges, responses and outcomes Securing the belt and road initiative (pp. 197-214): Springer.

Irshad, M. S. (2015). One belt and one road: dose China-Pakistan economic corridor benefit for Pakistan's economy? Journal of Economics and Sustainable Development, 6(24).

Irshad, M. S., Xin, Q., Xuan, P., \& Arshad, H. (2016). Deltoid analysis of Pakistan-ASEAN-China free trade agreements and opportunities for Pakistan. Asian Economic and Financial Review, 6(5), 228-237.

Javaid, P. D. U., \& Haq, M. A. U. (2020). Political Challenges and Security Issues in FATA and its impact on Economic Development. South Asian Studies, 31(1). 
Javaid, U. (2016). Assessing CPEC: potential threats and prospects. Journal of the Research Society of Pakistan, $53(2)$.

Javaid, U., \& Jahangir, A. (2015). Pakistan-China strategic relationship: A glorious journey of 55 years. Journal of the Research Society of Pakistan, 52(1).

Javaid, U., \& Javaid, R. (2016). Strengthening geo-strategic bond of Pakistan and China through geo-economic configuration. Pakistan Economic and Social Review, 54(1), 123-142.

Johnson, C. K. (2016). President Xi Jinping's 'Belt and Road'Initiative. Center for Strategic and International Studies, 28, 1-24.

Kalim, D. (2020). Gwadar port: serving strategic interests of Pakistan. South Asian Studies, 31(1).

Keesing, D. B. (1967). Outward-looking policies and economic development. The Economic Journal, 303-320.

Khan, H. U. (2017). China Pakistan Economic Corridor (CPEC): Benefits for Pakistan.

Kneller, R., Bleaney, M. F., \& Gemmell, N. (1999). Fiscal policy and growth: evidence from OECD countries. Journal of public economics, 74(2), 171-190.

Kreutzmann, H. (2009). The Karakoram highway as a prime exchange corridor between Pakistan and China. Paper presented at the Regional workshop, Integrated tourism concepts to contribute to sustainable development in mountain regions, Gilgit, Pakistan and Kashgar, China, 8-14 Oct, 2008.

Krueger, A. O. (1997). Trade policy and economic development: how we learn: National Bureau of Economic Research.

Lall, S., \& Narula, R. (2004). Foreign direct investment and its role in economic development: do we need a new agenda? The European Journal of Development Research, 16(3), 447-464.

Lee, D., \& Hudson, D. (2004). The old and new significance of political economy in diplomacy. Review of International Studies, 343-360.

Lenka, S. K., \& Sharma, P. (2014). FDI as a main determinant of economic growth: a panel data analysis. Annual Research Journal of Symbiosis Centre for Management Studies, Pune, 1, 84-97.

Lim, A. C.-H. (2015). Africa and China's 21st century maritime silk road: East Asian Institute, National University of Singapore.

Lindberg, L. N. (1963). The political dynamics of European economic integration. The political dynamics of European economic integration.

Liu, W., \& Dunford, M. (2016). Inclusive globalization: Unpacking China's belt and road initiative. Area Development and Policy, 1(3), 323-340.

Liu, W., Zhang, Y., \& Xiong, W. (2020). Financing the Belt and Road Initiative. Eurasian Geography and Economics, 61(2), 137-145.

Lu, S., \& Ram, R. (2001). Foreign aid, government policies, and economic growth: Further evidence from crosscountry panel data for 1970-1993. Economia Internazionale/International Economics, 54(1), 15-29.

Malik, A. R. (2018). The China-Pakistan Economic Corridor (CPEC): a game changer for Pakistan's economy China's Global Rebalancing and the New Silk Road (pp. 69-83): Springer.

Mumtaz, M. Z., Smith, Z. A., \& Khan, A. H. (2017). An analysis of Chinese outward foreign direct investment in emerging and developing countries: implications for Pakistan under CPEC. The Journal of Social, Political, and Economic Studies, 42(3/4), 327-367.

Nijkamp, P., \& Poot, J. (2004). Meta-analysis of the effect of fiscal policies on long-run growth. European Journal of Political Economy, 20(1), 91-124.

Nikomborirak, D., \& Jitdumrong, S. (2013). ASEAN trade in services. The ASEAN Economic Community: A work in progress, 95-140.

Ohashi, H. (2018). The Belt and Road Initiative (BRI) in the context of China's opening-up policy. Journal of Contemporary East Asia Studies, 7(2), 85-103.

Olds, K. (2002). Globalization and urban change: Capital, culture, and Pacific Rim mega-projects. OUP Catalogue.

Ozturk, I. (2008). The role of education in economic development: a theoretical perspective. Available at SSRN 1137541.

Psacharopoulos, G., \& Ng, Y. C. (1992). Earnings and education in Latin America: assessing priorities for schooling investments (Vol. 1056): World Bank Publications.

Rafi, A. E. (2017). Terrorism, India and CPEC.

Saeed, K. (1986). The dynamics of economic growth and political instability in developing countries. System Dynamics Review, 2(1), 20-35.

Sharma, B. K., \& Kundu, N. D. (2016). China's one belt one road: Initiative, challenges and prospects: Vij Books India Pvt Ltd.

Sial, S. (2014). The China-Pakistan Economic Corridor: an assessment of potential threats and constraints. Conflict and Peace Studies, 6(2), 24.

Sultan, M. F., Omar, M., \& Imtiaz, R. (2019). Analyzing prevalent internal challenges to china pakistan economic 
corridor (cpec) through public opinion. Journal of Economics and Sustainable Development, 10(7).

Swaine, M. D. (2015). Chinese views and commentary on the 'One Belt, One Road'initiative. China Leadership Monitor, 47(2), 3.

Taylor, G. (2008). Evolution's edge: The coming collapse and transformation of our world: New Society Publishers.

Tschirgi, N. Y. o., Lund, M. S., \& Mancini, F. (2010). Security and development: Searching for critical connections: Lynne Rienner Publishers London/Boulder.

Tse, E. (2010). The China strategy: harnessing the power of the world's fastest-growing economy: Basic Books.

Turnovsky, S. J. (1999). Fiscal policy and growth in a small open economy with elastic labour supply. canadian Journal of Economics, 1191-1214.

Wekesa, C. T., Wawire, N. H., \& Kosimbei, G. (2016). Effects of infrastructure development on foreign direct investment in Kenya. Journal of Infrastructure Development, 8(2), 93-110.

Wood, F. (2002). The Silk Road: two thousand years in the heart of Asia: Univ of California Press.

Zaki, M. A. (2014). The evolution in global power balance and Pak-China relations. Policy Perspectives: The Journal of the Institute of Policy Studies, 11(2), 3-15.

Zukin, S. (2012). Competitive Globalization and Urban Change. Rethinking Global Urbanism, 17-22. 